\title{
TRIPLED BEST PROXIMITY POINT THEOREM IN METRIC SPACES
}

\author{
Yeol Je Cho, Animesh Gupta, Erdal Karapinar, Poom Kumam and \\ WUTIPHOL SINTUNAVARAT
}

\begin{abstract}
The purpose of this article is to first introduce the notion of tripled best proximity point and cyclic contraction pair. We also establish the existence and convergence theorems of tripled best proximity points in metric spaces. Moreover, we apply our results to setting of uniformly convex Banach space. Finally, we obtain some results on the existence and convergence of tripled fixed point in metric spaces and give illustrative examples of our theorems.
\end{abstract}

Mathematics subject classification (2010): 47H10, 54H25, 46J10, 46J15.

Keywords and phrases: Tripled fixed point, tripled Common Fixed Point, tripled best proximity point.

\section{REFERENCES}

[1] M. Abbas, W. Sintunavarat, P. Kumam, Coupled fixed point of generalized contractive mappings on partially ordered G-metric spaces, Fixed Point Theory Appl. 2012, 31 (2012).

[2] A. D. ARVAnitakis, A proof of the generalized Banach contraction conjecture, Proc. Am. Math. Soc. 131 (12), 3647-3656 (2003).

[3] R. P. Agarwal, M. A. Alghamdi, N. Shahzad, Fixed point theory for cyclic generalized contractions in partial metric spaces, Fixed Point Theory Appl., 2012, 2012:40.

[4] S. BANACH, Sur les opérations dans les ensembles abstraits et leurs applications aux équations intégrales, Fund. Math. 3 (1922) 133-181.

[5] S. S. BASHA, Best proximity point theorems generalizing the contraction principle, Nonlinear Anal. 74, 5844-5850 (2011).

[6] S. S. Basha, P. Veeramani, Best approximations and best proximity pairs, Acta. Sci. Math. (Szeged) 63, 289-300 (1997).

[7] S. S. Basha, P. Veeramani, Best proximity pair theorems for multifunctions with open fibres, J. Approx. Theory 103, 119-129 (2000).

[8] S. S. Basha, P. Veeramani, D. V. Pai, Best proximity pair theorems, Indian J. Pure Appl. Math. 32, 1237-1246 (2001).

[9] M. BORCUT, V. BERINDE, Tripled fixed point theorems for contractive type mappings in partially ordered metric spaces, Nonlinear Anal. 74 (15), 4889-4897 (2011).

[10] D. W. Boyd, J. S. W. Wong, On nonlinear contractions, Proc. Am. Math. Soc. 20, 458-464 (1969).

[11] B. S. Choudhury, K. P. Das, A new contraction principle in Menger spaces, Acta Math. Sin. 24 (8), 1379-1386 (2008).

[12] A. A. Eldred, P. Veeramani, Existence and convergence of best proximity points, J. Math. Anal. Appl. 323, 1001-1006 (2006).

[13] K. FAN, Extensions of two fixed point theorems of F. E. Browder, Math. Z. 112, 234-240 (1969).

[14] T. GNANA-Bhaskar, V. LaKshmikantham, Fixed point theorems in partially ordered metric spaces and applications, Nonlinear Anal. TMA 65, 1379-1393 (2006).

[15] D. Guo, V. Lakshmikantham, Coupled fixed points of nonlinear operators with applications, Nonlinear Anal., Theory Methods Appl. 11 (1987) 623-632.

[16] E. Karapinar, Fixed point theory for cyclic weak $\phi$-contraction, Appl. Math. Lett., 24 (2011) 822 825.

[17] E. Karapinar, K. Sadarangani, Fixed point theory for cyclic $(\phi, \psi)$ contractions, Fixed Point Theory Appl. 2011:69, (2011). 
[18] E. Karapinar, I. M. Erhan, A. Y. Ulus, Fixed Point Theorem for Cyclic Maps on Partial Metric Spaces, Appl. Math. Inf. Sci. 6 (2012), no. 1, 239-244.

[19] E. Karapinar, I. M. Erhan, Cyclic Contractions and Fixed Point Theorems, Filomat, 26 (2012), no. $4,777-782$.

[20] E. Karapinar, Best Proximity Points Of Cyclic Mappings, Appl. Math. Lett., 25 (2012), 1761-1766.

[21] S. KARPAGAM AND S. AgRAWAL, Best proximity points theorems for cyclic Meir-Keeler contraction maps, Nonlinear Anal., 74 (2011) 1040-1046.

[22] W. A. Kirk, P. S. SrinaVaSan and P. Veeramani, Fixed points for mapping satisfying cylical contractive conditions, Fixed Point Theory, 4 (2003), 79-89.

[23] J. Merryfield, B. Rothschild, J. D. JR. Stein, An application of Ramsey's theorem to the Banach contraction principle, Proc. Am. Math. Soc. 130 (4), 927-33 (2002).

[24] C. Mongkolkeha, P. Kumam, Best proximity point Theorems for generalized cyclic contractions in ordered metric spaces, J. Opt. Theory Appl. 155 (1), 215-226 (2012).

[25] C. Mongkolkeha, Y. J. Cho And P. Kumam, Best proximity points for generalized proximal Ccontraction mappings in metric spaces with partial orders, Journal of Inequalities and Applications 2013, 2013:94.

[26] C. MongKolKeha And P. Kumam, Best proximity points for asymptotic proximal pointwise weaker Meir-Keeler-type $\psi$-contraction mappings, Journal of the Egyptian Mathematical Society (2013), http://dx.doi.org/10.1016/j.joems.2012.12.002.

[27] J. P. PROLla, Fixed point theorems for set valued mappings and existence of best approximations, Numer. Funct. Anal. Optim. 5, 449-455 (1983).

[28] V. M. SEHGAL, S. P. Singh, A generalization to multifunctions of Fan's best approximation theorem, Proc. Am. Math. Soc. 102, 534-537 (1988).

[29] V. M. Sehgal, S. P. Singh, A theorem on best approximations, Numer. Funct. Anal. Optim. 10, 181-184 (1989).

[30] W. Sintunavarat, Y. J. Cho, P. Kumam, Coupled coincidence point theorems for contractions without commutative condition in intuitionistic fuzzy normed spaces, Fixed Point Theory Appl. 2011, 81 (2011).

[31] W. Sintunavarat, Y. J. Cho, P. Kumam, Coupled fixed point theorems for weak contraction mapping under F-invariant set, Abstr. Appl. Anal. 2012, 15 (Article ID 324874) (2012).

[32] W. Sintunavarat, P. Kumam, Coupled best proximity point theorem in metric spaces, Fixed Point Theory Appl. 2012, 93 (2012).

[33] T. SUZUKI, A generalized Banach contraction principle that characterizes metric completeness, Proc. Am. Math. Soc. 136 (5), 1861-1869 (2008).

[34] T. SuzUKi, M. KiKKAWA, C. Vetro, The existence of best proximity points in metric spaces with the property UC, Nonlinear Analysis: Theory, Methods \& Applications 71 (7-8), 2918-2926 (2009).

[35] V. Vetrivel, P. Veeramani, P. Bhattacharyya, Some extensions of Fan's best approximation theorem, Numer. Funct. Anal. Optim. 13, 397-402 (1992).

[36] K. Wlodarczy , R. Plebaniak, A. Banach, Best proximity points for cyclic and noncyclic setvalued relatively quasi-asymptotic contractions in uniform spaces, Nonlinear Anal. 70 (9), 3332-3342 (2009).

[37] K. Wlodarczy , R. Plebaniak, A. Banach, Erratum to: best proximity points for cyclic and noncyclic set-valued relatively quasi-asymptotic contractions in uniform spaces, Nonlinear Anal. 71, 3583-3586 (2009).

[38] K. WLODARCZy , R. Plebaniak, A. BANACH, Best proximity points for cyclic and noncyclic setvalued relatively quasi-asymptotic contractions in uniform spaces, Nonlinear Anal. 70, 3332-3341 (2009).

[39] K. Wlodarczyk, R. Plebaniak, C. Obczynski, Convergence theorems, best approximation and best proximity for set-valued dynamic systems of relatively quasi-asymptotic contractions in cone uniform spaces, Nonlinear Anal. 72, 794-805 (2010). 